\title{
Open innovation laboratories for social modeling sustainable society sensitive to social needs
}

\author{
José Antonio Yañez-Figueroa \\ Tecnológico de Monterrey \\ Secretaría de Educación de Veracruz \\ Talabarteros No. 70, U. H. San José, \\ Orizaba, Veracruz, México. C.P. 94330 \\ (+52) 12721346828 \\ jantonio.yanezf@tecvirtual.mx
}

\author{
María Soledad Ramírez-Montoya \\ Escuela de Educación, Humanidades y \\ Ciencias Sociales \\ Tecnológico de Monterrey \\ Avda. Garza Sada 2501 sur; col. \\ Tecnológico \\ Monterrey, N. L. México; CP64849 \\ (+52) 18110445381 \\ solramirez@itesm.mx
}

\author{
Francisco J. García-Peñalvo \\ Computer Science Department / Science \\ Education Research Institute / GRIAL \\ Research Group Universidad de \\ Salamanca \\ Distinguished Professor of the Escuela de \\ Humanidades y Educación, Tecnológico \\ de Monterrey, México \\ fgarcia@usal.es
}

\begin{abstract}
This research is framed in the field of laboratories citizens, especially those who are driven by private institutions of higher education. The variables are going to study the interaction of participants of laboratories, the use of technology and how to participate in a working group when different disciplines are integrated. The main objective is to analyze how the collaborative knowledge construction is achieved when you have a common problem or social impact. Since the mixed paradigm is to enrich the information to be retrieved and analyzed to answer the research question. The instruments are designed questionnaires, in-depth interviews, non-participant observation and analysis of the productions of the participants. This project seeks to find information to know in depth the mechanisms of collaborative knowledge construction. Such construction will be used as input for participants to be active in the ways of responding to societal challenges.
\end{abstract}

Categories and Subject Descriptors

- Applied computing Collaborative learning • Social and professional topics $\sim$ Sustainability

\section{Keywords}

Collaborative knowledge construction; social innovation labs (laboratories); open innovation.

\section{CONTEXT AND MOTIVATION THAT DRIVES THE RESEARCH}

Social Innovation Labs (SIL) are a community that is responsible for consuming, modify and produce products or services with the interaction in a real scenario; in order to analyze, design, study and exchange information, to build and share knowledge through traditional or digital media, which Lazalde, Torres and Vila-Viñas $[21 ; 12]$ have called for educational innovation ecosystems. These ecosystems are ideal places to study collaborative knowledge construction processes in the field of educational innovation [28;29]. In these open, free, collaborative and inclusive ICT environments interdisciplinary encounters are provided to address urgent problems of society. The information provided by users, the research method to collect it and analyze it, conclusions that develop new solutions and interaction in the context of real life [26]: In a Social Innovation Labs aspects must be present.

The SIL scenarios arise as to foster innovation that addresses social needs and not subject exclusively to the interests of the industry. These laboratories may be driven by public institutions or experiences that emerge from social activism movements [11]. In education it is still a challenge to know how from educational institutions can be driven an experience of this kind. A strategic stage to observe the OpenLabs initiative is an SIL organized by the Tecnológico de Monterrey (www.openlabs.mx), as part of a project called "Binational Laboratory for the Intelligent Management of Energy Sustainability and Technological Training" (funded by the National Science and Technology and the Ministry of Energy). SIL concrete initiative is part of the challenge of this private university by exploring new educational models to position itself as a leading institution in Latin America in the formation of new citizens of the knowledge society [18].

\section{STATE-OF-THE-ART}

In recent years, citizens have multiplied laboratories as social participation initiatives that use digital technology as a platform to connect and collaborate. Have proposed different terms to refer to these experiences, as laboratories citizens [37 ; 39], City Labs [31], Open Labs [9], Living Labs [23] and Commons Laboratories [10]. Unlike the above, the term Social Innovation Labs (SIL), emphasizes the fact that collaboration is aimed at generating new solutions to common problems of the participants $[36 ; 20]$. Among the characteristics mentioned in the SIL is the organization in horizontal network of participants [27], the collaborative use of technology and interdisciplinarity [11]. In this regard, in various laboratories they converge interaction models, using technologies and diversity of participants.

Another feature that you should pay the SIL is the ability they have to facilitate the Collaborative Knowledge Construction [CKC]. CKC is meant to generate knowledge through collaborative networks between actors with common $[5 ; 22]$ interests. A special laboratory is more intensive use of digital media to create collaborative networks, production and transfer of resources that often are digital in nature and 
willingness to share that knowledge on open platforms $[35 ; 24]$. Unlike what happens expected in formal educational settings, laboratories knowledge that emerges is the product of the interests, problems and abilities of participants, since it is they who define their own agenda. This last Reigosa [38] has been called open innovation.

With regard to the above and to strengthen the topic of open innovation, it can be mentioned that this scenario has a close relationship with the open education movement, which in essence seeks to promote activities of various communities focused on collaboration to create knowledge open type. Authors [34] have explained that the open education movement seeks to make knowledge for the common good, and open the possibility of reducing the gap in access to information strengthening actions to share, use, reuse and create knowledge with the support of ICT.

This movement is based on a document called "The Berlin Declaration on Open Access". Its main goal is that open access is cultural heritage and a source of knowledge for all human beings. Also they exhibit two characteristics for products to be considered open access: 1) If you allow free access to all users who can modify the content and use it for personal use for any purpose but giving credit to the author; 2) provide a means for knowledge is available to anyone, through print or digital media. With the above it seeks to benefit society with the knowledge generated in any field [25].

In short, both the open education movement, ICT and social innovation labs are factors involved in the dissemination of knowledge, where stakeholders and concerned about the development and growth of societies emerge. This paradigm is not closed to academia, and citizens are also building means and ways to socialize knowledge through effective actions are in hand with the evolution of digital technologies. The authors [13] use the term open science that empowers the citizen, the expert, researcher, scientist and anyone who seeks to create, transfer and store scientific or empirical knowledge to give way to open knowledge management.

When it comes to educational settings, formal and non-formal contexts are included. Where ICT have intervened to strengthen lifelong learning practices for collaboration and open spaces. For its part, UNESCO [43] has promoted the creation of policies to consolidate the open state with clear aims to use the knowledge and pass on the best means to reach the entire population movement. Promoting sustainable development and ensuring partnerships between school-university, government, private enterprises, social organizations and ordinary citizens to diversify the ways to meet the challenges of the knowledge society and to promote open educational movement.

In this area of the creation of open knowledge and emerging scenarios knowledge management as social innovation labs, important challenges related to loom: the achievement of a correlation between actors in a society (interaction and interdisciplinary collaborative work); strengthening the links between the various agencies of society (opening to open innovation); the consolidation of a culture of lifelong learning as an input for the collaborative knowledge construction (from formal and informal settings); ensuring that communities of practice serve as a platform to the knowledge to be socialized by digital and print media from open formats, free and open access [3].

For its part, in the context of the SIL, open format technology plays a key role in open innovation. In that sense, open innovation is a strategy that allows participants to share their experience without limits of space and time $[42 ; 13]$ for the group the use and co-creation of innovative responses to troubleshoot the immediate context is achieved. Therefore, ICT transcend its role as a tool and become an open meeting environment, relationship networking, dissemination and collaboration $[15 ; 14]$. Eventually, as a result of such open interaction, there may be new ways of thinking about a problem, specific alternative solutions, new resources and new forms of organization for resolving these problems.

The impact study of the SIL is still incipient, lack empirical evidence to know what the variables that could impact positively on the generation of collaborative knowledge for solving common problems are. Literature describes some of these significant variables such as interaction, the use of open technology and participation of individuals with various disciplines $[2 ; 4]$. In the interaction of these variables we can ask what determines the collaborative knowledge construction to generate solutions to the problems of the participants? Specifically, how influence patterns of interaction, the use of technology and the diyersity of participants in the development of solutions to their shared problems in a context of open innovation?

\section{HYPOTHESIS AND OBJECTIVES Hypothesis}

If there are models of decentralized interaction, collaborative use of digital technology and wide variety of participants in a Social Innovation Labs, quality innovation applied to the solution of their problems shared knowledge will be generated.

Null hypothesis

If the interaction of the participants has a high degree of centralization, some collaborative use of technology and the profile of participants is homogeneous is not collaboration will generate innovative knowledge relevant to the solution of their problems.

\section{General objective}

The objective of this research is to analyze the conditions under which the shared knowledge construction generates significant open innovation to solve the problems of the participants, by assessing the experiences of projects in a social innovation labs, in an educational context open directed to the energy sector, in order to prototype a laboratory model of social innovation with an evaluation system that will generate sustainable societies patterns sensitive to social needs.

\section{Specific objectives}

1) To compare different models of Social Innovation Labs, collaborative practices and social contributions.

2) Analyze how participants experience the knowledge construction processes in a laboratory of social innovation, to determine the relationship with the innovative solution of problems from the open approach. 
3) Draw a laboratory prototype model of social innovation as open collaborative environments and knowledge building, with its evaluation system, to share with open licenses.

\section{RESEARCH APPROACH AND METHODS}

\subsection{Research Method}

The research method is characterized by mixed investigate a problem from the techniques of quantitative and qualitative research [7]. The study will work with two phases, the first phase a questionnaire to participants SIL of different projects will be applied to investigate their disciplinary fields, interaction models perceived and how they use open technology and in the second phase will conduct interviews nonparticipating observations and analysis of the production generated in the projects $[40 ; 30]$. A study was conducted Quan-QUAL will allow quantitative data from -information numerically, to deepen with qualitative data -from the voice of participants- because it seeks to eliminate as far as possible biases one approach and enrich the results with different types of data $[19 ; 6]$.

\subsection{Population and sample}

The population will consist of the total participants of the calls for Ciudades que aprenden, Laboratorio Ciudadano de Energía and Laboratorio ciudadano, approximately 300 participants. Of the total a random sample is selected to generate numerical and narrative data to a dimension of contrast between the two types of data collected [4], in order to enrich the results to analyze in depth the conditions of the collaborative knowledge construction.

\subsection{Study variables and instruments}

Social Innovation Labs (SIL): defined as an educational scenario citizen initiatives of co-creating answers to everyday problems involving experience and open science in mid environments by technological tools in order to distribute information to enrich from different disciplinary [17] perspectives.

Collaborative Knowledge Construction (CKC) is conceived as the action of creating knowledge through collaboration and interaction of people with different disciplines in a network environment horizontal participation with the use of technological tools for global solutions to local problems [20].

Open Innovation (OI) is the use of open network of digital media to build knowledge through interaction of diverse people who share information and knowledge that is built in a collaborative and interdisciplinary [23].

\subsubsection{Tools and Techniques}

These variables will be analyzed with the following instruments and techniques:

- Questionnaires to retrieve information from the disciplinary fields of participants, as well as to determine the patterns of interaction and type of use of technology in the social innovation labs (variable: collaborative knowledge construction).

- In-depth interviews: with promoters laboratory, collaborators and mediators of social innovation labs in the construction of shared knowledge (Variables: social innovation labs and collaborative knowledge construction).

- Remarks nonparticipating: with an observation guide to detect the variables of knowledge construction are evident in the interactions of the participants (Variable: collaborative knowledge construction).

Analysis of the production generated in the projects: in order to determine the solutions given to problems in networking laboratory (Variable: open innovation).

\subsection{Sources of Information}

- Participants: whose collaborative processes and knowledge construction are the main object of this study.

- Generated products: with special attention to products that have left a digital record, either because they are technological applications (applications for mobile devices, digital learning objects, programming codes, etc.) or because they are resources that can be shared and reused in internet (videos, computer graphics, websites, blogs, etc.).

- Employees of social innovation labs: with special attention to those who play the role of "mediators", who are the main way to help organize the interaction of participants and direct it towards the generation of innovation.

- The promoters of the laboratory: agents who had some responsibility in the organization and management of the event.

\subsection{Capture and analyze information}

- Development of questionnaires for the first phase

- Application of questionnaires as a pilot

- Enrich questionnaires based on the results of the pilot test

- Application of questionnaires to participants selected for the sample

- Analysis of quantitative data with SPSS

- Drafting of the results of the quantitative phase 
- Preparation of interviews and observation guides for the second phase

- Implementation of interviews and observations as a pilot

- Improve interviews and observations based on the pilot

- Implementation of interviews and comments to selected participants for the sample

- Analysis of the data of the second phase information triangulation and Atlas.ti

- $\quad$ Drafting of the results of the qualitative phase

\section{DATA ANALYSIS}

From the mixed approach, as already it mentioned quantitative and qualitative data that will be analyzed in their subassemblies to complete with exercise depth inquiry to construct valid and reliable conclusions and results of the joint research [32] are recovered. In the quantitative phase the Content Validity coefficient [16] is used to determine the internal consistency reliability was determined through Cronbach's Alpha [8]. To construct validity Rasch method, based on the item response theory [1] will be used. On the qualitative side, to determine the validity and reliability of the instruments were triangulated data in a triple input box in order to retrieve information representative of subject treated from different sources and instruments [33]. The rights of participants will be preserved: a privacy, anonymity, confidentiality and to hold accountable the researcher [41].

\section{MEDIA AND RESOURCE MATERIALS}

- Parcel office: Excel, Word: to capture, store and analyze the different methods mentioned.

- Social Innovation Labs: Ciudades que aprenden proyect part of Tecnológico de Monterrey to recover the practices carried out in these scenarios and document what happens in relation to the collaborative knowledge construction.

- Questionnaires, depth interviews and online interviews: to retrieve information directly from participants related skills and knowledge developed during their participation in the citizen laboratory.

- Digital Repositories and physical products of the participating laboratories studied to analyze and find related or not the characteristics of open, collaborative and interdisciplinary innovation.

- SPSS: This software is used to analyze quantitative data

- Atlas.ti: This software is used to analyze qualitative data

\section{DISSERTATION STATUS}

At the time of submitting this paper the thesis is in the first phase. The documentation of the different models of laboratories is being done. The access to the models is possible through their web sites. It is important to point out that the partners have agreed to share information with the researcher to learn about his practices and his social contributions throughout the history of these laboratories contributions.

\section{CURRENT AND EXPECTED CONTRIBUTIONS}

Laboratory practices are closely related to the open source of knowledge and how can it be used, reused and transformed by others considering license free use of the information. In social innovation labs also integrate people with different disciplines who carry out collaborative work for the intervention designmeets the needs of those affected.

With regard to the expected contributions must be with the participation of the research documenting the first experience of citizen laboratory driven by a private university in Mexico and to allow him to deepen the knowledge of the practices carried into a laboratory and analyze end products as possible answers to social problems and determine whether they are an innovative solution. It will also seek contact with more scenarios citizens laboratories to gather information to get to answer the research questions and to determine the factors involved in the collaborative knowledge construction through interaction of interdisciplinary groups in order to develop a true open innovation in the educational field.

\section{ACKNOWLEDGEMENTS}

This research work has been completed within the Ph.D. in Education in the Knowledge Society of the University of Salamanca, Spain.

The study has been recorded in the framework of Project 266632 "Binational Laboratory for the Intelligent Management of Energy Sustainability and Technological Training", with financing from the CONACYT-SENER Energy Sustainability Fund (call: S0019 $\neg 2014 \neg 01)$ The author is grateful for the Fund's support and to Tecnológico de Monterrey as the project manager.

Many thanks also to the SNTE-56 for its assistance in obtaining the permits from the Veracruz Ministry of Education to attend the International Congress of Technological Ecosystems for Enhancing Multiculturality, in the city of Salamanca, Spain.

\section{REFERENCES}

[1] Abad, J., Garrido, J., Olea, J., \& Ponsoda, V. (2006). Teoría clásica de los test y Teoría de la Respuesta al ítem. Madrid: UAM.

[2] Almirall, E., Lee, M., y Wareham, J. (2012). Mapping Living Labs in the Landscape of Innovation Methodologies. Technology Innovation Management Review, 2(9). Retrieved from http://timreview.ca/article/603 
[3] Atkins, D. E., Brown, J. S., \& Hammond, A. L. (2007). A review of the open educational resources (OER) movement: Achievements, challenges, and new opportunities. Retrieved from Menlo Park, CA, USA: http://www.hewlett.org/uploads/files/ReviewoftheOERMovement.pdf

[4] Castellanos, J. C., \& Onrubia, J. (2015). La regulación compartida en entornos de aprendizaje colaborativo: Una revisión del estado de la investigación empírica. Education in the Knowledge Society, 16(3), 57 - 72. http://doi.org/http://dx.doi.org/10.14201/eks20151635772

[5] Charles, T., \& Fen, Y. (2006). Mixed Methods Sampling: A Typology With Examples. Journal of Mixed Methods Research, 1(1), 77. http://doi.org/10.1177/2345678906292430

[6] Creswell, J. W, Plano Clark, V. L., Guttmann, M. L., \& Hanson, E. E. (2003). Advanced mixed methods research design. En A.Tashakkori y C. Teddlie (Eds.). Handbook of mixed methods in social and behavioral research (pp. 209-240). Thousand Oaks, CA: Sage

[7] Creswell, J. W. (2013). Research design: Qualitative, quantitative, and mixed methods approaches. Sage publications. Retrieved from http://isites.harvard.edu/fs/docs/icb.topic1334586.files/2003_Creswell_A Framework for Design.pdf

[8] Cronbach, L. J. (1951). Coefficient alpha and internal structure of test. Psychometrika, 16 (3), 297-333. Retrieved from $\mathrm{http}: / / \mathrm{kttm} . h o a s e n . e d u . v n /$ sites/default/files/2011/12/22/cronbach_1951_coefficient_alpha.pdf

[9] Di Meglio, A., Gaillard, M., \& Purcell, A. (2014). CERN openlab Whitepaper on Future IT Challenges in Scientific Research. Zenodo, 56. http://doi.org/10.5281/zenodo.8765

[10] Estalella, A., Rocha, J., \& Lafuente, A. (2013). "Laboratorios de procomún: experimentación, recursividad y activismo". Teknokultura, v. 10, n. 1, pp. 21-48. http://teknokultura.net/index.php/tk/article/view/121

[11] Finquelievich, S. (2007). Innovación, tecnología y prácticas sociales en las ciudades: hacia los laboratorios vivientes. Revista iberoamericana de ciencia tecnología y sociedad, 3(9), 135 - 152. Retrieved from http://www.scielo.org.ar/scielo.php?script=sci_arttext\&pid=S1850-00132007000200009\&lng=es\&nrm=iso\&tlng=es

[12] Freire, J., \& Schuch-Brunet, K. (2010). Políticas y prácticas para la construcción de una Universidad Digital. La Cuestión Universitaria, (6), 85 - 94. Retrieved from https://dialnet.unirioja.es/servlet/articulo?codigo $=3840956$

[13] García-Peñalvo, F. J., García de Figuerola, C., \& Merlo, J. A. (2010). Open knowledge: Challenges and facts. Online Information Review, 34(4), 520-539. http://dx.doi.org/10.1108/14684521011072963

[14] García. M. A., González, V., \& Ramos, C. (2010). Modelos de interacción en entornos virtuales de aprendizaje. Revista Electrónica de Estudios Filológicos, (19), 27. Retrieved from http://www.um.es/tonosdigital/znum19/subs/indice

[15] Hafkesbrink, J., \& Schroll, M. (2011). Innovation 3.0: embedding into community knowledge-collaborative organizational learning beyond open innovation. Journal of Innovation Economic \& Management, 1(7), 55-92. Retrieved from http://www.cairn.info/revuejournal-of-innovation-economics-2011-1-page-55.htm.

[16] Hine, C. (2004). Etnografía virtual. Colección Nuevas tecnologías y sociedad. Barcelona, España: Editorial UOC

[17] Innovación Ciudadana en Iberoamérica. (2016). Laboratorios ciudadanos: espacios para la innovación ciudadana. Retrieved from $\mathrm{http} / /$ ciudadania20.org/labsciudadanos/

[18] ITESM. (2015). Modelo Educativo del Tecnológico de Monterrey. Proceso formativo. México: Instituto Tecnológico y de Estudios Superiores de Monterrey. Retrieved from

http://www.itesm.mx/wps/wcm/connect/TPESM/Tecnologico+de+Monterrey/Nosotros/Modelo+educativo/Modelo+educativo+del+Tecn ologico+de+Monterrey/

[19] Johnson, R. B. \& Onwuegbuzie, A. J. (2004). Mixed methods research: A research paradigm whose time has come. Educational Researcher, 33(7), 14-26.

[20] Kosfeld, M., \& von Siemens, F. (2011). Competition, Cooperation, and Corporate Culture. The RAND Journal of Economics, 42(1), 23 - 43. http://doi.org/10.1111/j.1756-2171.2010.00124.x

[21] Lazalde, A., Torres, J., \& Vila-Viñas, D. (2015). Hardware: Ecosistemas de innovación y producción basados en hardware libre. In Buen Conocer / FLOK Society Modelos sostenibles y políticas públicas para una economía social del conocimiento común y abierto en el Ecuador (v. 2.0, pp. 619-652). Retrieved from http://book.floksociety.org/ec/4/4-1-hardware-ecosistemas-de-innovacion-y-produccionbasados-en-hardware-libre/

[22] Llinares, S. (2012). Construcción de conocimiento y desarrollo de una mirada profesional para la práctica de enseñar matemáticas en entornos en línea. Avances de Investigación en Educación Matemática, 2, 53-70. Retrieved from https://scholar.google.com.mx/scholar?hl=es\&q=Construcci $\% \mathrm{C} 3 \% \mathrm{~B} 3 \mathrm{n}+\mathrm{de}+$ conocimiento $+\mathrm{y}+\mathrm{desarrollo}+\mathrm{de}+$ una + mirada + profesional $+\mathrm{p}$ ara + la + pr $\% \mathrm{C} 3 \% \mathrm{~A} 1$ ctica + de + ense $\% \mathrm{C} 3 \% \mathrm{~B} 1$ ar+matem $\% \mathrm{C} 3 \% \mathrm{~A} 1$ ticas + en+entornos + en $+1 \% \mathrm{C} 3 \% \mathrm{ADnea} \& \mathrm{btnG}=\& 1 \mathrm{r}=$

[23] Magdala, M., \& Pedruzzi, L. (2013, May). Profundizando la comprensión de los Living Labs de Brasil. Revista Iberoamericana de Ciencia, Tecnología y Sociedad, 8(23), 231-247. Retrieved from http://www.redalyc.org/articulo.oa?id=92427464013

[24] Martínez-Torres, R. (2013). Análisis de las comunidades de innovación abierta desde la perspectiva del Análisis de Redes Sociales. Intangible Capital, 9(1), 46-54. http://doi.org/http://dx.doi.org/10.3926/ic.352

[25] Max-Planck-Gesellschaft Society. (2003). Berlin Declaration on Open Access to Knowledge in the Sciences and Humanities. Retrieved from http://openaccess.mpg.de/Berlin-Declaration 
[26] Molina-Jordá, J. M. (2012). Herramientas virtuales: laboratorios virtuales para Ciencias Experimentales - una experiencia con la herramienta VCL. In X Jornadas de Redes de Investigación en Docencia Universitaria: la participación y el compromiso de la comunidad universitaria (Vol. X, pp. 2689 - 2702). Universidad de Alicante. Retrieved from http://rua.ua.es/dspace/handle/10045/24277

[27] Mortero-Fleta, B., \& Pérez-Sabater, C. (2011). Knowledge construction and knowledge sharing: a Wiki-based approach. Procedia Social and Behavioral Sciences, 28, 622-627. Retrieved from http://www.sciencedirect.com/science/article/pii/S1877042811025572

[28] Murray, R., Caulier-Grice, J., \& Mulgan, G. (2010). The open book of social innovation. London: National endowment for science, technology and the art.

[29] Nicholas, C. A., \& Fowler, J. H. (2010). Conectados: El sorprendente poderde las redes sociales y cómo nos afectan. Barcelona, España: Taurus

[30] Onwuegbuzie, A. J., \& Collins, K. M. T. (2007). A Typology of Mixed Methods Sampling Designs in Social Science Research. The Qualitative Report, 12(2), 281 - 316. Retrieved from http://nsuworks.nova.edu/tqr/vol12/iss2/9/

[31] Open Labs. (2016). OpenLabs. Acerca de. Tecnológico de Monterrey. Escuela de Educación, Humanidades y Ciencias Sociales. México: ITESM. Retrieved from http://www.openlabs.mx/acerca-de/

[32] Ortega, I., \& Villar, R. (2014). El modelo Media Lab: contexto, conceptos y clasificación. Posibilidades de una didáctica artística en el entorno revisado del laboratorio de medios. Pulso: revista de educación, (37), 149 - 165. Retrieved from http://dialnet.unirioja.es/ejemplar/386721

[33] Poblete, C. (2013). Métodos mixtos: una aproximación a sus ventajas y limitaciones en la investigación de sistemas y servicios de salud. Revista Chilena de Salud Pública, 17(3), 218-223. Retrieved from http://www.revistasaludpublica.uchile.cl/index.php/RCSP/issue/view/2589

[34] Ramírez Montoya, M. S., \& García-Peñalvo, F. J. (2015). Movimiento Educativo Abierto. Virtualis, 6(12), 1-13.

[35] Ramírez-Montoya, M. S. (2013). Triangulación e instrumentos para análisis de datos [vídeo]. Disponible en la Escuela de Graduados en Educación de la Universidad Virtual del Tecnológico de Monterrey. Retrieved from http://apps05.ruv.itesm.mx/portal/uvtv/video/video.jsp?folio=4626

[36] Ramírez-Montoya, M. S. (2015). Acceso abierto y su repercusión en la Sociedad del Conocimiento: Reflexiones de casos prácticos en Latinoamérica. Education In The Knowledge Society (EKS), 16(1), 103-118. doi:10.14201/eks2015161103118

[37] Red CreAtiva. (s. f.). Laboratorios de innovación social. Valencia, España: Red CreAtiva. Retrieved from http://www.redcreactiva.org/laboratorios-de-innovacion-social

[38] Reigosa, C. (2012). Un estudio de caso sobre la comunicación entre estudiantes en el laboratorio escolar. Revista Electrónica de Enseñanza de las Ciencias, 11(1), 98-119.

[39] Schiavo, E., \& Serra, A. (2013). Laboratorios ciudadanos e innovación abierta en los sistemas CTS del siglo XXI. Una mirada desde Iberoamérica. Revista Iberoamericana de Ciencia, Tecnología y Sociedad, 8(23), 115-121. Retrieved from http://www.redalyc.org/articulo.oa?j $=92427464007$

[40] Soler-Pérez, V. (2008). Uso de las TIC como herramienta didáctica en el aula. Contribuciones a las Ciencias Sociales. Retrieved from http://www.eumed.net/rev/cccss/02/vsp.htm

[41] Tashakkori, A. \& Teddlie, C. (2003). Handbook of Mixed Methods in Social \& Behavioral Research. Thousand Oaks CA, EE.UU.: Sage

[42] Tuckman, B. W., \& Harper, B. E. (2012). Conducting educational research. Maryland, United Kingdom: Rowman \& Littlefield Publishers.

[43] UNESCO. (2012). 2012 Paris OER Declaration. Retrieved from http:/www.unesco.org/new/fileadmin/MULTIMEDIA/HQ/CI/CI/pdf/Events/Paris\%20OER\%20Declaration_01.pdf 